УдК 343.85(043.3)

\author{
Н. М. Бакаянова
}

\title{
ОСНОВИ, ЗАСАДИ ТА ПРИНЦИПИ АДВОКАТУРИ: СПІВВІДНОШЕННЯ ПОНЯТЬ
}

Постановка проблеми. Важлива роль у захисті прав та основних свобод людини й громадянина належить адвокатурі. Відповідно до ст. 1312 Конституції України адвокатура діє для надання професійної правничої допомоги; тільки адвокати здійснюють захист і представництво в суді, крім випадків, встановлених законом. Конституційні положення мають вирішальне значення для розуміння ролі адвокатури в суспільних відносинах, проте на сучасному етапі судово-правової реформи продовжується розвиток законодавства про адвокатуру та адвокатську діяльність. Реформа адвокатури та сфери надання правової допомоги зумовлює необхідність підвищеної уваги й до визначення термінології, змісту понять, які застосовує законодавець щодо питань організації адвокатури та здійснення адвокатської діяльності.

Зміни до Конституції України призвели до заміни терміну «основи організації та діяльності адвокатури» у ст. 92 на термін «засади». Термін «засади організації та діяльності адвокатури та здійснення адвокатської» використовується у положеннях ст. 1312 Основного закону. Закон України «Про адвокатуру та адвокатську діяльність» застосовує термін «засади» поряд із терміном «принципи» щодо організації та діяльності адвокатури. Термін «принципи» містять «Правила адвокатської етики». У зв'язку із цим з метою розвитку теорії адвокатури, належного розвитку законодавства про адвокатуру та адвокатську діяльність є нагальна потреба визначення понять «основи», «засади» та «принципи», з'ясування їх співвідношення.

Аналіз останніх досліджень та публікацій. Питання адвокатури розглядаються у працях вітчизняних вчених М.Р. Аракеляна, В.Г. Гончаренка, Т.В. Варфоломєєвої, Т.Б. Вільчик, Я.П. Зейкана, М.А. Погорецького, О.Д. Святоцького, О.В. Синєокого, Д.П. Фіолевського, С.Я. Фурси, О.Г. Яновської та багатьох інших. Проте поняття «основи адвокатури» не досліджувалося, а питання засад і принципів, що характеризують ад- 
вокатуру та іï основи, досліджено недостатньо. У працях О.I. Козяр, К.M. Северина, А.О. Чаленко та інших науковців більшою мірою акцентовано увагу на дослідженні прямо визначених законодавством принципів. Залишено поза межами цих досліджень інші основоположні засади організації та діяльності адвокатури, що обумовлює необхідність подальшої розробки доктринальних положень у зазначеному напрямі.

Метою статті є визначення понять «основи», «засади» та «принципи» адвокатури, з'ясування співвідношення цих понять.

Виклад основного матеріалу. Термін «основи» в законодавстві України використовується досить широко. Так, існує ціла низка законів із застосуванням цього терміну у їхній назві: Закон «Про основи соціального захисту бездомних осіб і безпритульних дітей» від 02.06.2005 № 2623-IV, Закон «Про основи соціальної захищеності інвалідів в Україні» від 21.03.1991 № 875-XII, Закон «Про основи національної безпеки України» від 19.06.2003 № 964-IV, Закон «Про основи містобудування» від 16.11.1992 № 2780-XII, Закон «Про організаційно-правові основи боротьби з організованою злочинністю» від 30.06.1993 № 3341-XII тощо.

$\mathrm{У}$ юридичній науці зазначений термін також охоче застосовується науковцями. Лише в назвах наукових праць з юриспруденції (монографій, дисертацій, статей) поняття «основи» вживається у таких поєднаннях: «правові основи» [1], «основи конституційного ладу» [2], «конституційні основи» [3], «конституційно-правові основи» [4], «теоретичні основи» [5], «теоретико-правові основи» [6], «доктринальні основи» [7], «фінансово-правові основи» [8], «інформаційно-правові основи» [9], «організаційно-правові основи» [10], «системні основи» [11] тощо. Проте що саме означають ці терміни, автори, що їх вживають, визначають досить рідко. Загалом лише наука конституційного права приділяє більш-менш належну увагу вивчення поняття «основ» у зв'язку з існуванням у ній такої категорії, як «основи конституційного (державного) ладу» [12].

Так, під основами державного ладу В.Ф. Погорілко розуміє систему основних принципів організації та діяльності держави та іiі основних інститутів: органів державної влади, основних функцій держави, інших елементів (атрибутів) держави [12, с. 156]. Розуміння основ через систему принципів висловлюють й Ю.С. Шемшученко [13, с. 13-14] та В.Ф. Годуванець [14, с. 50]. Таке розуміння основ, на наш погляд, грунтується на тому, що поняття «основа», «основи» є термінами, через які власне й визначаються більш поширені у мові та юриспруденції терміни «принцип» («принципи») та «засада» («засади»).

Наприклад, словник української мови Б. Грінченка поняття «засади» визначає як «підгрунтя, основа» [15, с. 92]. За словником С. Ожегова, «принцип - це переконання, основне засадне положення», «засада - першоджерело, основа, принципи, основні положення» [16, с. 561, 640]. За словником В. Даля «принцип - це наукова або етична засада, правило, основа, від якої не відступають», а «засада - джерело, основа» $[17$, с. 431,494$]$. Узагальнивши використання відповідної термінології в 
праві, Р.Л. Іванов зробив висновок, що досить часто терміни «принципи права», «юридичні принципи», «засадничі ідеї», «відправні начала», «керівні положення» використовують як синоніми [18, с. 115]. Отже, у філології терміни «основи», «засади» та «принципи» є синонімами, а у юриспруденції вони теж розглядаються як синонімічні.

Утім, є розуміння «основ» як значно ширшої за своїм змістом категорії, аніж синонім понять «принципи» чи «засади».

Так, наприклад, під конституційною основою державного будівництва і місцевого самоврядування А.М. Колодій та А.Ю. Олійник розуміють відповідні матеріальні та процесуальні конституційні норми та інститути, а також процесуальні конституційні правовідносини, що регулюються названими нормами [19, с. 22].

О. Рум'янцев під час дослідження поняття основ конституційного ладу робить висновок, що термін «основи» - поняття більш широке, і розрізняє дві його сторони. По-перше, основи є реальними суспільними відносинами, які існують об'єктивно та на які накладається конституційний лад. I по-друге, це особливий конституційно-правовий інститут. «Основи» в широкому плані О. Рум'янцев пропонує поділяти на три рівні: 1) головні цінності; 2) власне основи конституційного ладу (у вузькому їх розумінні), тобто основні принципи, які визначають його сутність; 3) конституційно-правові інститути й норми, за допомогою яких вищезазначені положення отримують безпосереднє обгрунтування, закріплення та юридичне значення. Усі ці рівні утворюють систему: цінності лежать в основі принципів, а останні конкретизуються в інститутах і нормах, що надає в підсумку всій цій системі правову значущість [20, с. 3-15].

Вживаються поняття «основи», «засади» чи «принципи» і щодо адвокатури. Так, наприклад, ст. 3 Закону «Про адвокатуру та адвокатську діяльність» передбачає, що правовою основою діяльності адвокатури України є Конституція України, цей Закон, інші законодавчі акти України, а ст. 4 Закону визначає принципи та засади здійснення адвокатської діяльності. При цьому ще донедавна редакція ст. 92 Конституції України передбачала, що виключно законами України визначаються основи організації та діяльності адвокатури. У зв'язку з внесенням змін до Конституції України Законом «Про внесення змін до Конституції України (щодо правосуддя)» від 02.06.2016 № 1401-VIII редакція статті була викладена так: «виключно законами України визначаються засади організації та діяльності адвокатури». У зв'язку із цим, може виникнути цілком логічне питання: чи означає заміна слова «основи» на «засади» у конституційній нормі зміну сфери виключного регулювання законами тих чи інших відносин щодо адвокатури? На наш погляд, навряд чи, проводячи таку заміну, український законодавець задавав собі це питання.

Виходячи зі ст. 4 Закону України «Про адвокатуру та адвокатську діяльність», яка має назву «Принципи та засади здійснення адвокатської діяльності», можна прийти до висновку, що принципи та засади як тер- 
міни мають самостійне значення. У ч. 1 ст. 4 зазначеного Закону встановлюється перелік принципів діяльності адвокатури, а у ч. ч. $2,3,4$ ст. 4 закріплюються загальні положення щодо здійснення адвокатської діяльності. Якщо звернутися до Закону України «Про прокуратуру», то можна прийти до висновку, що засади містять як основоположні ідеї (принципи), так і положення, які породжуються цими основоположними ідеями та розкривають їх. Так, наприклад, засади політичної нейтральності прокуратури та недопустимості незаконного втручання прокуратури в діяльність органів законодавчої, виконавчої та судової влади - по суті, принципи, які є продовженням зазначених у цій же нормі основоположних принципів, таких як законність, справедливість, неупередженість та об'єктивність, незалежність прокурорів (ч. 1 ст. 3).

Взагалі ж вбачається, що дискусія щодо співвідношення категорій «основи», «засади» чи «принципи» є проявом особливостей сучасного стану національної юридичної науки з гносеологічної точки зору, які, за справедливим твердженням В. Селіванова, полягають у певній невизначеності іï методологічних і теоретичних підвалин та установок $[21$, с. 23$]$. Тому допоки в науці, правотворчій чи правозастосовній практиці не досягнуто єдності щодо розуміння цих понять, їх тлумачення буде здійснюватися довільно, виходячи із завдань, що стоять перед суб'єктом тлумачення у тому чи іншому разі. Утім, будь-яке вживання в наукових дослідженнях терміну, що є дискусійним у науці, повинне бути обумовлене автором задля розуміння термінології, того теоретичного підгрунтя чи тієї основи, на якій будується це дослідження.

Висновки. Отже, можна запропонувати розуміти під основами адвокатури сукупність ії головних цінностей, принципів, основоположних інститутів і норм, які визначають адвокатуру як правове явище. Принципи адвокатури є, таким чином, іiї основами, але поряд з іншими складовими елементами. Принципами адвокатури України є основоположні, керівні ідеї, основні вихідні положення та закономірності, на яких грунтується організація та діяльність адвокатури і здійснення адвокатської діяльності. Засади за своєю суттю максимально наближені до принципів, але такі положення є більш розкритими та деталізованими.

На наш погляд, необхідності розуміння поняття «основи адвокатури» як синоніму «принципів адвокатури» чи «засад адвокатури» немає. Загалом використання синонімів у науці можливе, проте здебільшого той чи інший термін, що використовується, повинен мати своє індивідуальне розуміння. При цьому слід відзначити, що тлумачення терміну має відображати розмежування з іншими термінами та визначати основні характеристики. Слід також відзначити, що поняття основ адвокатури застосовується до різних складових елементів адвокатури. У зв'язку із цим функціональні та організаційні основи адвокатури різняться між собою та $є$ тими характеристиками, що визначають іiі головні цінності, принципи, основоположні інститути та норми у функціональному та організаційному аспектах. 


\section{Література}

1. Правові основи військового будівництва та військово-цивільних відносин : збірник законодавчих актів з питань національної безпеки і оборони / [ред. рада : Г.К. Крючков (голова), Б.П. Андресюк, В.П. Горбулін та ін.]. - К. : Парламентське вид-во, 2005. - 832 с.

2. Тодика Ю.М. Основи конституційного ладу України : [монографія] / Ю.М. Тодика. Х. : Факт, 2000. - 176 с.

3. Чуйко З.Д. Конституційні основи національної безпеки України : автореф. дис. ... канд. юрид. наук : спец. 12.00.02 / 3.Д. Чуйко / Нац. юрид. акад. України ім. Я. Мудрого. X., 2008. -20 c.

4. Любченко П.М. Конституційно-правові основи розвитку місцевого самоврядування як інституту громадянського суспільства : [монографія] / П.М. Любченко. - Х. : Одіссей, 2006. 352 c.

5. Боднарчук О.Г. Теоретичні основи та адміністративно-правові механізми протидії корупції в Державній кримінально-виконавчій службі України : [монографія] / О.Г. Боднарчук ; Нац. ун-т держ. податк. служби України. - К. : Центр учб. літ., 2015. - 461 с.

6. Гейда О.В. Теоретико-правові основи організації та діяльності політичних партій в Україні : автореф. дис. ... канд. юрид. наук : спец. 12.00.01 / О.В. Гейда ; Нац. ун-т внутр. справ. - Х., 2005. - 20 с.

7. Шутак І.Д. Доктринальні основи юридичної техніки / І.Д. Шутак / / Європейські перспективи. - 2013. - № 4. - С. 5-9.

8. Руденко В.М. Фінансово-правові основи соціального захисту населення (порівняльний аналіз законодавства України, Федеративної Республіки Німеччини та інших зарубіжних країн-членів Європейського Союзу) : автореф. дис. ... канд. юрид. наук : спец. 12.00.07 / В.М. Руденко ; Київський ун-т ім. Тараса Шевченка. - К., 1999. - 18 с.

9. Іванов Д.А. Інформаційно-правові основи забезпечення безпеки мореплавства : автореф. дис. ... канд. юрид. наук : спец. 12.00.07 / Д.А. Іванов ; кер. роботи С.О. Кузнецов ; Нац. ун.-т «Одеська юридична академія». - Одеса, 2008. - 19 с.

10. Ярічевська Л.В. Організаційно-правові основи місцевого самоврядування (порівняльний аспект) / Л.В. Ярічевська / / Державне будівництво та місцеве самоврядування. Вип. 6. Х. : Право, 2003. - С. 57-63.

11. Іваницький С.О. Системні основи адвокатури / С.О. Іваницький / / Вісник Запорізького національного університету. Юридичні науки. - 2015. - № 4 (1). - С. 20-26.

12. Конституційне право України : [підручник] / за ред. В.Ф. Погорілка. - К. : Наук. думка, 1999. $-734 \mathrm{c}$

13. Шемшученко Ю.С. Основи конституційного ладу України / Ю.С. Шемшученко // Конституційне право України. Академічний курс : [підручник] : у 2 т. / за заг. ред. Ю.С. Шемшученка. - Т. 2. - К. : Юрид. думка, 2008. - 800 с.

14. Годованець В.Ф. Конституційне право України : [навч. посіб.] / В. Ф. Годованець. К. : МАУП, 2005. - 360 с.

15. Словник української мови : в 4 т. / упоряд. $з$ дод. влас. матеріалу Б. Грінченко ; НАН України. Ін-т укр. мови. - К. : Наук. думка, 1996. - Т. 2. О-П. - 573 с.

16. Ожегов С.И. Словарь русского языка / С.И. Ожегов. - М. : Русский язык, 1977. 847 c.

17. Даль В.И. Толковый словарь живого великорусского языка : в 4 т. / В.И. Даль. - М. : Русский язык, 1989 - Т. 3. - 1990. - 556 с.

18. Иванов Р.Л. О понятии принципов права / Р.Л. Иванов / / Вестник Омского университета. - 1996. - № 2. - С. 115-118.

19. Колодій А.М. Державне будівництво і місцеве самоврядування: [навч. посібник] / А.М. Колодій, А.Ю. Олійник ; Національна академія внутрішніх справ України. - К. : Юрінком Інтер, 2000. - 304 c.

20. Румянцев О.Г. Основы конституционного строя: понятие, содержание, отражение в Конституции / О.Г. Румянцев / / Государство и право. - 1993. - С. 3-15.

21. Селіванов В. До проблеми методологічного забезпечення теоретичного аналізу державотворення і правотворення в Україні / В. Селіванов / / Право України. - 2006. - № 4. C. $21-28$. 


\section{Анот т ц і я}

Бакаянова Н. М. Основи, засади та принципи адвокатури: співвідношення понять. - Стаття.

У статті досліджуються співвідношення понять «основи», «засади» та «принципи», які застосовуються в законодавстві про адвокатуру та адвокатську діяльність. Основи адвокатури - це сукупність їі головних цінностей, принципів, основоположних інститутів і норм, які визначають адвокатуру як правове явище. Принципами адвокатури України є основоположні, керівні ідеї, основні вихідні положення та закономірності, на яких грунтується організація та діяльність адвокатури і здійснення адвокатської діяльності. Засади є положеннями, які за своєю суттю максимально наближені до принципів, але більш розкриті та деталізовані. Таким чином, необхідності розуміння поняття «основи адвокатури» як синоніму понять «принципи адвокатури» чи «засади адвокатури» немає. Загалом використання синонімів у науці можливе, проте здебільшого той чи інший термін, що використовується, повинен мати своє індивідуальне розуміння.

Ключові слова: адвокатура, наука про адвокатуру, адвокатологія, принципи адвокатури, теорія адвокатури.

\section{Аннота ция}

Бакаянова Н. М. Основы, основные положения и принципы адвокатуры: соотношение понятий. - Статья.

В статье исследуется соотношение понятий «основы», «основные положения» и «принципы», которые применяются в законодательстве об адвокатуре и адвокатской деятельности. Основы адвокатуры - это совокупность тех ее главных ценностей, принципов, основополагающих институтов и норм, которые определяют адвокатуру как правовое явление. Принципами адвокатуры Украины являются основополагающие, руководящие идеи, основные исходные положения и закономерности, на которых основывается организация и деятельность адвокатуры и осуществление адвокатской деятельности. Основные положения, по своей сути, максимально приближены к принципам, но являются более раскрытыми и детализированными. Таким образом, нет необходимости восприятия понятия «основы адвокатуры» как синонима понятий «принципы адвокатуры» или «основные положения об адвокатуре». В целом, использование синонимов в науке возможно, однако в большинстве случаев тот или иной термин, который используется, должен иметь свое индивидуальное содержание.

Kлючевые слова: адвокатура, наука об адвокатуре, адвокатология, принципы адвокатуры, теория адвокатуры.

\section{S u m m a r y}

Bakayanova $N$. M. The fundamentals, basics and principles of advocacy: the ratio of concepts. - Article.

This article examines the relationship between the concepts of "basis", "fundamentals" and "principles" that apply in the legislation on legal profession and advocacy. Fundamentals of advocacy are the combination of values, principles, fundamental institutions and norms that define the advocacy as a legal phenomenon. Principles of advocacy of Ukraine are the fundamental, guiding idea, key assumptions and patterns underlying the organization of advocacy and advocate activity. The basics, in essence, as close as possible to the principles, but are more open and detailed. Thus, there is no need of understanding the concepts "fundamentals of advocacy" as synonymous with "principles of advocacy" or "basics of advocacy". Generally, the use of synonyms in science is possible, but in most cases, a particular term that is used must have its individual contents.

Key words: advocacy, advocacy science, advocatology, principles of advocacy, theory of advocacy. 